\title{
Brca1 is involved in tolerance to adefovir dipivoxil-induced DNA damage
}

\author{
HAO LIU ${ }^{1 *}$, YANG WU $^{2 *}$, FANG HE $^{3 *}$, ZIYUAN CHENG $^{1}$, ZILU ZHAO $^{1}$, CUIFANG XIANG $^{1}$, \\ XIAOYU FENG ${ }^{1}$, XIN BAI $^{1}$, SHUNICHI TAKEDA ${ }^{4}$, XIAOHUA WU ${ }^{2}$ and YONG QING ${ }^{1}$
}

\author{
${ }^{1}$ Department of Pharmacology, West China School of Pharmacy, Sichuan University; ${ }^{2}$ State Key Laboratory of Biotherapy \\ and Cancer Center, ${ }^{3}$ Center of Infectious Diseases, West China Hospital, Sichuan University, Chengdu, Sichuan 610041, \\ P.R. China; ${ }^{4}$ Department of Radiation Genetics, Graduate School of Medicine, Kyoto University, Kyoto 606-8501, Japan
}

Received November 18, 2018; Accepted March 29, 2019

DOI: $10.3892 / \mathrm{ijmm} .2019 .4164$

\begin{abstract}
Nucleos(t)ide analogues (NAs) are currently the most important anti-viral treatment option for patients with chronic hepatitis B (CHB). Adefovir dipivoxil (ADV), a diester pro-drug of adefovir, has been widely used for the clinical therapy of hepatitis B virus infection. It has been previously reported that adefovir induced chromosomal aberrations (CAs) in the in vitro human peripheral blood lymphocyte assay, while the genotoxic mechanism remains elusive. To evaluate the possible mechanisms, the genotoxic effects of ADV on the TK6 and DT40 cell lines, as well as DNA repair-deficient variants of DT40 cells, were assessed in the present study. A karyotype assay revealed ADV-induced CAs, particularly chromosomal breaks, in wild-type DT40 and TK6 cells. A $\gamma$-H2AX foci formation assay confirmed the presence of DNA damage following treatment with ADV. Furthermore, Brcal $^{-1-}$ DT40 cells exhibited an increased sensitivity to ADV, while the
\end{abstract}

Correspondence to: Dr Yong Qing, Department of Pharmacology, West China School of Pharmacy, Sichuan University, No. 17, Section 3, People's South Road, Chengdu, Sichuan 610041, P.R. China E-mail: qingyong@scu.edu.cn

Dr Xiaohua Wu, State Key Laboratory of Biotherapy and Cancer Center, West China Hospital, Sichuan University, No. 17, Section 3, People's South Road, Chengdu, Sichuan 610041, P.R. China

E-mail:wuxh@scu.edu.cn

*Contributed equally

Abbreviations: HBV, hepatitis B virus; cccDNA, covalently closed circular DNA; NAs, nucleos(t)ide analogues; CHB, chronic hepatitis B; ETV, entecavir; ADV, adefovir dipivoxil; DSBs, double-strand DNA breaks; CPT, camptothecin; DMSO, dimethyl sulfoxide; $\mathrm{IC}_{50}, 50 \%$ inhibiting concentration; ISCN, International System for Human Cytogenetic Nomenclature; WT, wild-type; CAs, chromosomal aberrations; BER, base excision repair; HR, homologous recombination; NHEJ, non-homologous end joining; TLS, translesion DNA synthesis; NER, nucleotide excision repair

Key words: adefovir dipivoxil, DNA damage, Brca1, DT40 cells, TK6 cells, homologous recombination knockdown of various other DNA damage-associated genes did not markedly affect the sensitivity. These comprehensive genetic studies identified the genotoxic capacity of ADV and suggested that Brcal may be involved in the tolerance of ADV-induced DNA damage. These results may contribute to the development of novel drugs against CHB with higher therapeutic efficacy and less genotoxicity.

\section{Introduction}

Chronic hepatitis B (CHB) is a major health problem worldwide (1). It is estimated that at least one-third of the world population have been infected with hepatitis $B$ virus (HBV) (2) and 240 million individuals are chronic carriers; however, a curative therapy remains unavailable (3). HBV, a hepadnaviridae, stabilizes in hepatocytes by forming covalently closed circular DNA (cccDNA) $(4,5)$. At present, nucleos(t)ide analogues (NAs) are one of the two major options for CHB treatment $(6,7)$. The NAs approved for HBV treatment include tenofovir alafenamide, entecavir (ETV) and adefovir dipivoxil (ADV). Although ADV has not been recommended as the first-line therapy, it is commonly used in numerous Asian countries due to the relatively lower resistance rate and lower cost compared with those of other therapies (6-10).

NAs markedly inhibit reverse transcriptase to reduce the DNA levels of HBV $(11,12)$. However, an increasing body of evidence has indicated that cccDNA stably attaches to the host hepatocyte genome in order to avoid elimination by NA $(4,11,13,14)$. Thus, the majority of patients require long-term NA therapy, even if HBV DNA has decreased to undetectable levels for a short time. Therefore, it is important to study the safety of NA therapy and the re-treatment efficacy following a relapse (15). By using specific assays, studies have determined that the nucleoside analogue ETV has genotoxic (16) and carcinogenic effects (17). Various types of DNA lesions, including single-strand DNA breaks, double-strand DNA breaks (DSBs), alkylation of DNA bases and covalent links between bases (intrastrand and interstrand crosslinks), may be caused by genotoxic chemicals (18). Unrepaired or incorrectly repaired lesions result in mutations and/or genetic instability, which may then be risk factors of carcinogenesis. In addition, the US prescription information sheet (19) states that ADV was indicated to be mutagenic in an 
in vitro mouse lymphoma cell assay. However, the underlying mechanisms of the genotoxicity of ADV remain elusive. Further studies are required to gain a better understanding of the genetic toxicity mechanisms of ADV. The DT40 cell line originates from a chicken B-lymphocyte line (20) and TK6 lymphoblastoid cells are a human-derived cell line (21-24). By using the wild-type $(W T)$ or specific gene knockout variants of these cell lines, the toxicity of ADV was evaluated and the underlying mechanisms were investigated in the present study.

\section{Materials and methods}

Chemicals. ADV (purity, $\geq 99 \%$ ) and camptothecin (CPT; purity, $\geq 99 \%$ ) were purchased from MedChemExpress (Monmouth Junction, NJ, USA). These chemicals were dissolved in dimethyl sulfoxide (DMSO). Stock solutions of ADV $(10 \mathrm{mM})$ and $\mathrm{CPT}(100 \mu \mathrm{M})$ were stored at $-20^{\circ} \mathrm{C}$ in aliquots. In each experiment, the final concentration of DMSO never exceeded $0.1 \%$.

Cell lines and cell culture. All of the cell lines used in the present study were provided by Professor Shunichi Takeda (Kyoto University, Kyoto, Japan). The DT40 cell lines (25-30) with different phenotypes used in the present study are summarized in Table I. The DT40 cells were incubated in RPMI-1640 medium containing 10\% newborn calf serum, $1 \%$ chicken serum, $1 \%$ penicillin streptomycin (all Wisent, Inc., St. Bruno, QC, Canada), $200 \mathrm{mM} \mathrm{L-glutamine} \mathrm{and} 50 \mu \mathrm{M}$ $\beta$-mercaptoethanol (both Gibco; Thermo Fisher Scientific, Inc., Waltham, MA, USA) with $5 \% \mathrm{CO}_{2}$ at $39.5^{\circ} \mathrm{C}$. The TK6 cells were routinely maintained in RPMI-1640 medium (Wisent, Inc.) including 10\% horse serum (Gibco; Thermo Fisher Scientific, Inc.) and $1 \%$ penicillin-streptomycin (Wisent Inc.) at $37^{\circ} \mathrm{C}$ in the presence of $5 \% \mathrm{CO}_{2}$. These sera (except chicken serum) were heat-deactivated at $56^{\circ} \mathrm{C}$ for $30 \mathrm{~min}$ prior to use.

Cell viability assay. The anti-proliferative effects of ADV and CPT on cells was determined with MTT assay (31-33). Briefly, the cells $\left(1 \times 10^{4}\right.$ cells $\left./ \mathrm{ml}\right)$ were seeded into 96 -well plates in complete medium, followed by incubation in the presence of various concentrations of ADV or CPT for $72 \mathrm{~h}$. The concentrations of ADV were $0,0.06,0.12,0.18,0.24$ and $0.3 \mu \mathrm{M}$ for DT40 cells or $0,1,2,3,4$ and $5 \mu \mathrm{M}$ for TK6 cells. The CPT concentrations were $0,10,20,30,40$ and $50 \mathrm{nM}$ for DT40 cells, or $0,2,4,6$ and $8 \mathrm{nM}$ for TK6 cells. The concentrations of CPT were $0,1,2,3,4$ and $5 \mathrm{nM}$, or 0,10 , 20, 30, 40 and $50 \mathrm{nM}$ for DT40 cells specifically for sensitivity experiments. DMSO $(<0.1 \%)$ was applied as a solvent and vehicle control with 3 replicates for each concentration of the drugs. Following $69 \mathrm{~h}$ treatment at $39.5^{\circ} \mathrm{C}$ for DT40 and at $37^{\circ} \mathrm{C}$ for TK6 cells, $20 \mu \mathrm{l}$ of $5 \mathrm{mg} / \mathrm{ml} \mathrm{MTT} \mathrm{(Amresco,}$ LLC, Solon, OH, USA) was added to the cells for $3 \mathrm{~h}$ at $39.5^{\circ} \mathrm{C}$ for DT40 and at $37^{\circ} \mathrm{C}$ for TK6 cells, and subsequently, the formazan dye crystals were dissolved by $50 \mu 1$ of $20 \%$ sodium dodecyl sulfate overnight at $39.5^{\circ} \mathrm{C}$ for DT40 and at $37^{\circ} \mathrm{C}$ for TK6 cells. The absorbance was detected at a wavelength of $570 \mathrm{~nm}$ by a microplate reader. The wells without cells served as a blank control. All the experiments were repeated at least 3 times. The $50 \%$ inhibitory concentration $\left(\mathrm{IC}_{50}\right)$ of the drugs on the cells was calculated with SPSS 25.0 software (IBM Corp, Armonk, NY, USA).

Chromosome aberration (CA) analysis. Preparation of chromosome samples was performed as described previously (34-37), with certain modifications. Briefly, cells $\left(2 \times 10^{5}\right.$ cells $\left./ \mathrm{ml}\right)$ were seeded in 6 -well plates and were treated with ADV or CPT in complete medium. DT40 cells were treated with 0.2 or $0.4 \mu \mathrm{M}$ ADV for $9-30 \mathrm{~h}$ and 5 or $25 \mathrm{nM}$ $\mathrm{CPT}$ for $6-24 \mathrm{~h}$ at $39.5^{\circ} \mathrm{C}$. TK6 cells were performed with $5 \mu \mathrm{M}$ ADV for $12-36 \mathrm{~h}$ and $2.5 \mu \mathrm{M}$ ADV for $12 \mathrm{~h}$ at $37^{\circ} \mathrm{C}$. Colcemid $(0.2 \mu \mathrm{g} / \mathrm{ml}$; Gibco; Thermo Fisher Scientific, Inc.) was added $3 \mathrm{~h}$ prior to harvesting in order to enrich mitotic cells. The cells were then incubated in $1 \mathrm{ml}$ hypotonic $\mathrm{KCl}$ solution (75 mM) for $25 \mathrm{~min}$ at room temperature. Subsequently, the cells were fixed with $3 \mathrm{ml}$ Carnoy's solution [methanol/acetic acid, 3:1, (v/v)] for $35 \mathrm{~min}$. A drop of this suspension was placed onto ethanol-washed glass slides and immediately dried by a flame. Finally, the dried slides were dyed with $5 \%$ Giemsa solution for $5 \mathrm{~min}$ at room temperature and carefully rinsed with water prior to air-drying. In the present study, 50 metaphase cells per each experiment were analyzed under a light microscope (magnification, x1,000). All assays were performed 3 times. A break or gap in a chromosome was evaluated and defined according to The International System for Human Cytogenetic Nomenclature (ISCN) (37).

Immunofluorescence analysis. $\gamma$-H2A histone family member $\mathrm{X}$ ( $\mathrm{H} 2 \mathrm{AX})$ formation is a rapid and sensitive cellular response to DSBs (38). Immunofluorescent staining was performed as reported previously (39). Briefly, cells $\left(2 \times 10^{5}\right.$ cells $\left./ \mathrm{ml}\right)$ cultured on 12-well-plates. DT40 cells were treated with $0.1 \mu \mathrm{M}$ ADV or $0.1 \mu \mathrm{M}$ CPT for 3,6 and $9 \mathrm{~h}$ at $39.5^{\circ} \mathrm{C}$, and TK6 cells were treated with $1 \mu \mathrm{M}$ ADV or $20 \mathrm{nM} \mathrm{CPT}$ for 3,6 and $9 \mathrm{~h}$ at $37^{\circ} \mathrm{C}$ and then harvested on glass slides. The cells were fixed with $3 \%$ paraformaldehyde for $10 \mathrm{~min}$ at room temperature followed by washing with PBS 3 times. The fixed cells were permeabilized with $0.1 \%$ Nonidet P-40 for $20 \mathrm{~min}$ at room temperature and washed with PBS again. Following blocking with $3 \%$ bovine serum albumin (cat. no. A8020; Beijing Solarbio Science \& Technology Co., Ltd., Beijing, China) for $30 \mathrm{~min}$ at room temperature, the cells were probed with anti- $\gamma-\mathrm{H} 2 \mathrm{AX}$ mouse monoclonal antibody (cat. no. 05-636; 1:1,000 dilution; EMD Millipore, Billerica, MA, USA) in a humidified environment at $4^{\circ} \mathrm{C}$ overnight. Following washing with PBS, the cells were incubated for $1 \mathrm{~h}$ at $37^{\circ} \mathrm{C}$ with Alexa Fluor 488-labeled goat anti-mouse $\mathrm{IgG}(\mathrm{H}+\mathrm{L})$ (cat. no. A0428; 1:1,000 dilution; Beyotime Institute of Biotechnology, Wuhan, China). The nuclei were stained with 4',6-diamidino-2-phenylindole for $10 \mathrm{~min}$ at room temperature. Finally, a fluorescence microscope (IX81; Olympus Corporation, Tokyo, Japan) was used to visualize the $\gamma$-H2AX foci (magnification, x1,000). The foci in 100 nuclei were counted. The visible foci as described in previous reports were counted by eye using Photoshop (version 12.0.3; Adobe Systems, Inc., San Jose, CA, USA) (40). The experiments were performed 3 times.

Statistical analysis. Statistical analysis was performed with SPSS 25.0 software (IBM Corp.). The statistically significant differences were determined with a Student's t-test or two-way 
Table I. DNA repair genes mutated in the analyzed DT40 clones.

\begin{tabular}{|c|c|c|c|}
\hline Author, year & Gene & Function & (Refs.) \\
\hline Sonoda et al, 2003 & $\operatorname{Rev} 3$ & TLS, HR (catalytic subunit of Pol $\zeta$ ) & $(25)$ \\
\hline Okada et al, 2002 & Xpa & Initial step of NER & $(26)$ \\
\hline Masson et al, 1998 & Parpl & $\begin{array}{l}\text { Poly (adenosine diphosphate) ribosylation, } \\
\text { associated with single-strand break and BER }\end{array}$ & $(27)$ \\
\hline Qing et al, 2011; Rosen, 2013 & Brcal & HR, NHEJ & $(28,30)$ \\
\hline Takata et al, 1998 & Ku70 & Initial step for NHEJ-dependent DSB repair & $(29)$ \\
\hline
\end{tabular}

analysis of variance with Tukey's post hoc test. Values are expressed as the mean \pm standard deviation. $\mathrm{P}<0.05$ was considered to indicate a statistically significant difference.

\section{Results}

ADV induces DSBs in WT DT40 and TK6 cells. Adefovir was previously demonstrated to induce CAs by a human peripheral blood lymphocyte assay in vitro without metabolic activation (19). As a diester prodrug of adefovir (19), it cannot be excluded that ADV may also has mutagenic effects. DSBs, one type of DNA damage, may be reliably identified by $\gamma$-H2AX foci detection (41). In the present study, DT40 and TK6 cells were continuously exposed to various concentrations of ADV for $72 \mathrm{~h}$ and CPT was used as a positive control. The results of the MTT assay indicated that ADV exerts a notable cytotoxic effect in WT DT40 and TK6 cells (Fig. 1). Furthermore, DT40 cells were treated with $0.1 \mu \mathrm{M}$ ADV for 3, 6 or $9 \mathrm{~h}$ to dynamically investigate the changes in the number of $\gamma-\mathrm{H} 2 \mathrm{AX}$ foci. In addition, TK6 cells were also exposed to $1 \mu \mathrm{M}$ ADV for the same durations. As presented in Figs. 2 and S1, the number of $\gamma$-H2AX foci was significantly increased following treatment with ADV and exhibited a peak at $6 \mathrm{~h}$. According to the quantitative distribution of $\gamma$-H2AX foci in WT DT40 and TK6 cells (Fig. S1), ADV induced a greater percentage of $\gamma$-H2AX-positive cells.

In addition, DNA damage was analyzed by measuring cytologically detectable CAs in mitotic cells. WT DT40 cells were exposed to 0.2 or $0.4 \mu \mathrm{M}$ ADV, and CAs were determined at 9, 12, 15, 24 and $30 \mathrm{~h}$. The maximum number of CAs was observed at $12 \mathrm{~h}$ of ADV treatment (Fig. 3A and B). Similarly, TK6 cells were exposed to $5 \mu \mathrm{M}$ ADV for $12-36 \mathrm{~h}$ and with $2.5 \mu \mathrm{M}$ ADV for $12 \mathrm{~h}$. CAs were determined at 12 , 24 and $36 \mathrm{~h}$. The maximum number of chromosomal breaks was observed at $12 \mathrm{~h}$ (Fig. 3C-E). These results confirmed that ADV was able to generate DNA DSBs in DT40 and TK6 cells.

Brcal $^{-1-}$ cells defective in DNA repair pathways are sensitive to $A D V$. To study the genotoxic mechanisms of ADV, an MTT assay using WT and mutant DT40 cells was performed. The sensitivity of ADV was assessed in a panel of DT40 clones, each of which was deficient in a different DNA repair pathway (Table I) (25-30). DT40 cells were treated with ADV at various concentrations for $72 \mathrm{~h}$. It was revealed that ADV inhibited cell growth in a dose-dependent manner (Fig. 4). As presented in Fig. 4A-C, only BrCal $^{-/-}(28,30)$ cells exhibited significant sensitivity to ADV. The present study also exposed WT and $\mathrm{BrCal}^{-/-}$DT40 cells to ADV and evaluated their cellular response using a colony survival assay (Data S1). Compared with WT DT40 cells, the colony survival of $\mathrm{BrCal}^{-/-}$cells was significantly reduced at 14 days (Fig. S2). The results of the clonogenic assays also confirmed this sensitivity (Fig. S2). The cell variants deficient in other DNA repair genes, including poly (adenosine diphosphate-ribose) polymerase 1 ( Parpl $\left.^{-/-}\right)$(27), REV3-like DNA directed polymerase $\zeta$ catalytic subunit $\left(\operatorname{Rev}^{-/}\right)(25), \mathrm{Ku}$ autoantigen $70 \mathrm{kDa}\left(K u 70^{-/-}\right)(29)$ and xeroderma pigmentosum group A-complementing protein $\left(\mathrm{Xpa}^{-/}\right)$(26), were not more sensitive to ADV than $W T$ cells (Fig. 4). In the present experiments, CPT was selected as a positive control (Fig. 4D-F).

Brcal deficiency sensitizes DT40 cells to ADV-induced CAs. In the present study, CAs were classified as chromosome or chromatid gaps, breaks and exchanges according to The ISCN (37). WT or Brcal ${ }^{-/}$DT40 cells were exposed to 0.2 or $0.4 \mu \mathrm{M}$ ADV for 9, 12, 15, 24 or $30 \mathrm{~h}$. Compared with $W T$ DT40 cells, Brcal ${ }^{-/-}$cells exhibited significantly increased CAs at 15, 24 and $30 \mathrm{~h}$, and the higher the dose the greater the increase in CAs observed (Fig. 5A and B). Notably, a monophasic pattern of CAs was induced in WT and $\mathrm{Brcal}^{-1-}$ cells. In these 2 cell lines, a peak was detectable at $12 \mathrm{~h}$ for WT and $24 \mathrm{~h}$ for $\mathrm{BrCal}^{-/}$cells, respectively, and it was much higher in $\mathrm{Brcal}^{-/-}$cells than in WT cells (Fig. 5A and B). As a positive control, WT and $\mathrm{BrCal}^{-1-}$ DT40 cells were treated with $5 \mathrm{nM}$ CPT for 6, 12, 18 and $24 \mathrm{~h}$ (Fig. 5C). At the same time, WT DT40 cells were treated with $25 \mathrm{nM}$ CPT (Fig. 5D). The results indicated that CPT induced more DNA damage in $\mathrm{Brcal}^{-/}$cells when compared with WT DT40 cells. These results further confirmed that Brcal participates in repairing ADV-induced DNA damage.

\section{Discussion}

NAs are effective inhibitors against reverse transcriptase to inhibit HBV DNA replication; however, NAs, including ETV, adefovir and ADV, have been reported to have genotoxic effects by various 

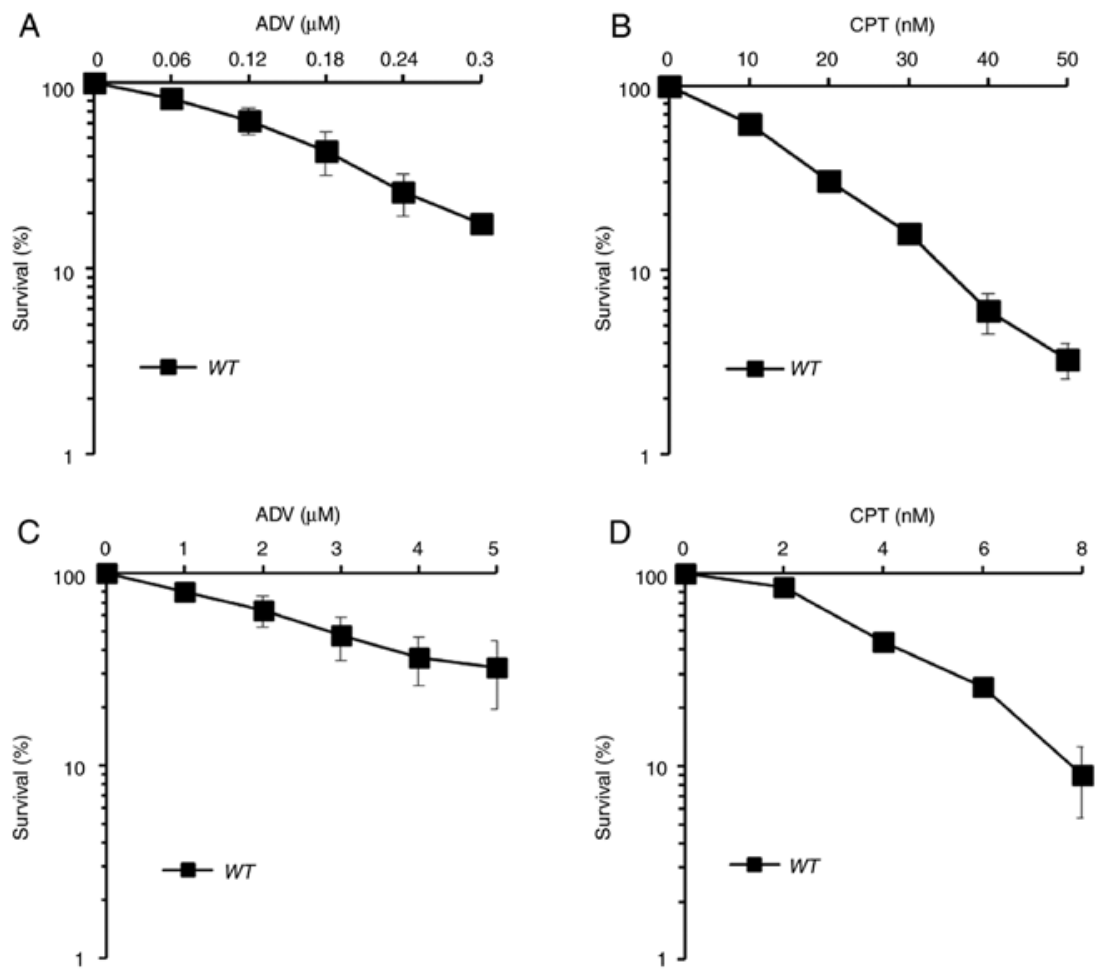

Figure 1. ADV reduces the survival of WT DT40 and TK6 cells. Sensitivity of WT DT40 cells to (A) ADV and (B) CPT. Sensitivity of WT TK6 cells to (C) ADV and (D) CPT. The x-axis represents the concentration of ADV or CPT and the y-axis represents the relative percentage of surviving cells at $72 \mathrm{~h}$. Survival data were log-transformed to approximate normality. ADV, adefovir dipivoxil; WT, wild-type; CPT, camptothecin.
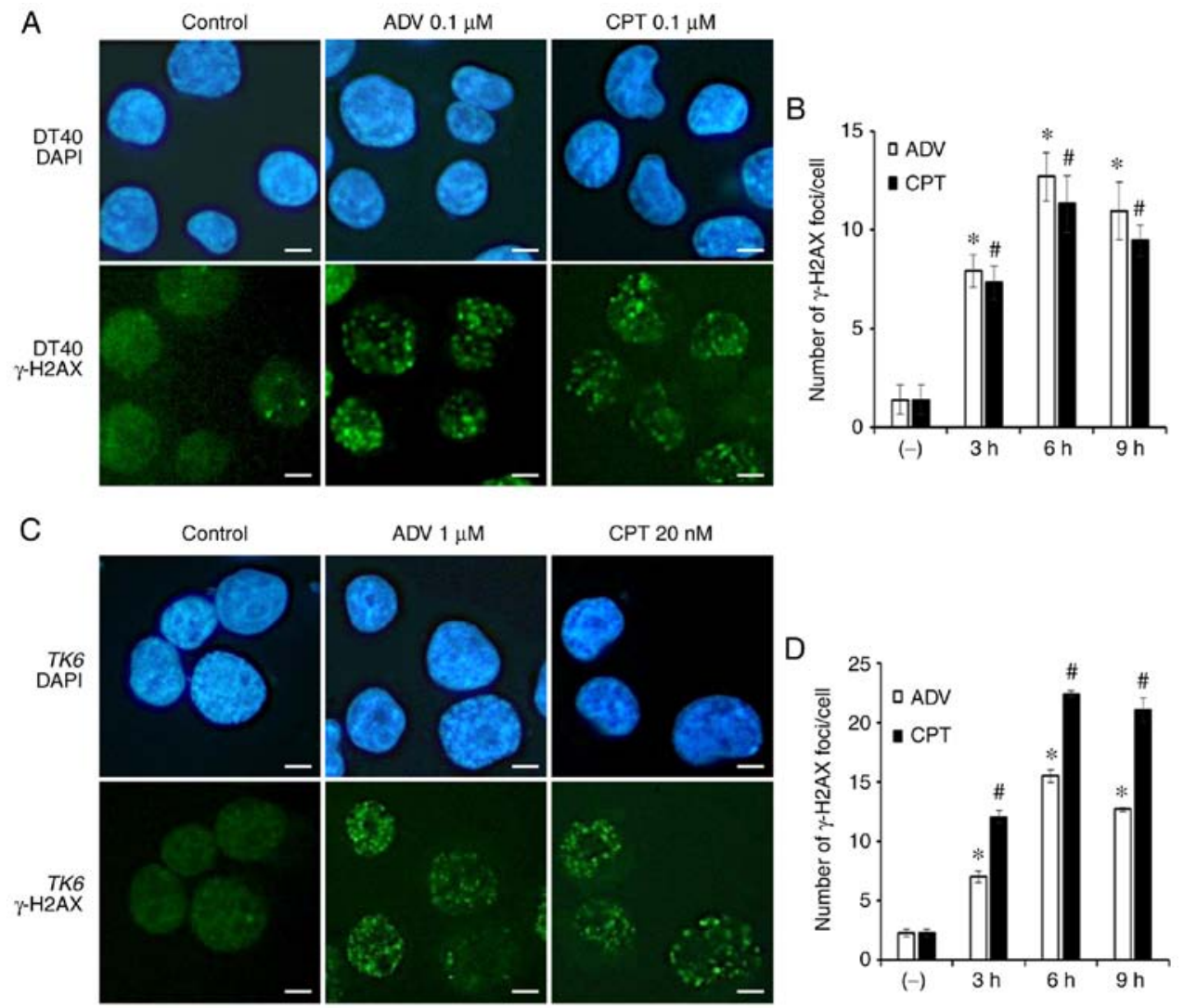

Figure 2. ADV induces the accumulation of $\gamma-\mathrm{H} 2 \mathrm{AX}$ in the nuclei of WTDT40 and TK6 cells. (A) Immunostaining of WTDT40 cells using an anti- $\gamma$-H2AX antibody and DAPI. Cells were treated with $0.1 \mu \mathrm{M}$ ADV or $0.1 \mu \mathrm{M} \mathrm{CPT}$ for $6 \mathrm{~h}$ (scale bar, $10 \mu \mathrm{M}$; magnification, $\mathrm{x} 1,000$ ). (B) Quantification of $\gamma$-H2AX foci in the nuclei of $W T$ DT40 cells treated with $0.1 \mu \mathrm{M}$ ADV or $0.1 \mu \mathrm{M}$ CPT for different durations. (C) Immunostaining of WT TK6 cells using an anti- $\gamma$-H2AX antibody and DAPI. Cells were exposed to $1 \mu \mathrm{M}$ ADV or $20 \mathrm{nM}$ CPT for $6 \mathrm{~h}$ (scale bar, $10 \mu \mathrm{M}$; magnification, $\mathrm{x} 1,000$ ). (D) Quantification of $\gamma$-H2AX foci in the nuclei of WT TK6 cells treated with $1 \mu \mathrm{M}$ ADV or $20 \mathrm{nM} \mathrm{CPT}$ for different durations. Values are expressed as the mean \pm standard deviation. "P<0.05 vs. ADV control; ${ }^{\#} \mathrm{P}<0.05$ vs. CPT control. ADV, adefovir dipivoxil; $\gamma$-H2AX, $\gamma$-H2A histone family member X; $W T$, wild-type; CPT, camptothecin; DAPI, 4',6-diamidino-2-phenylindole. 
A

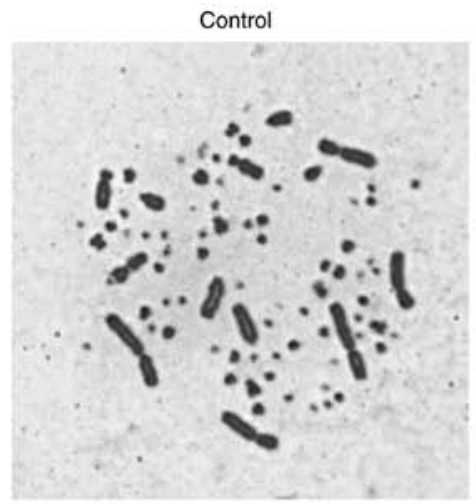

B

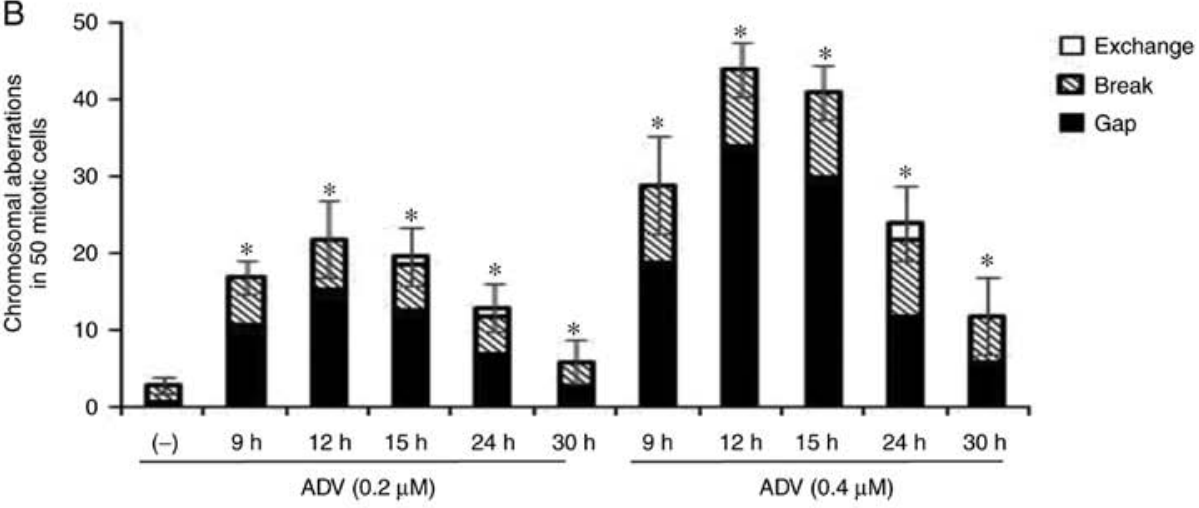

C

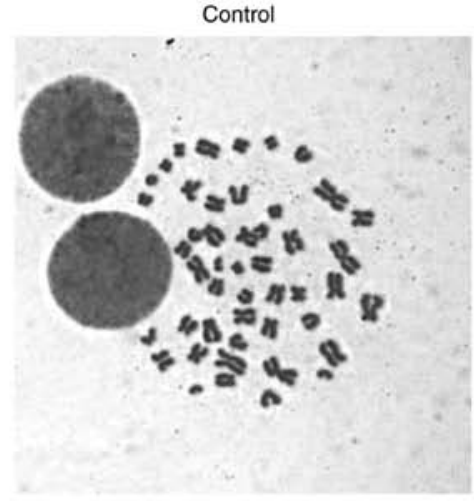

D

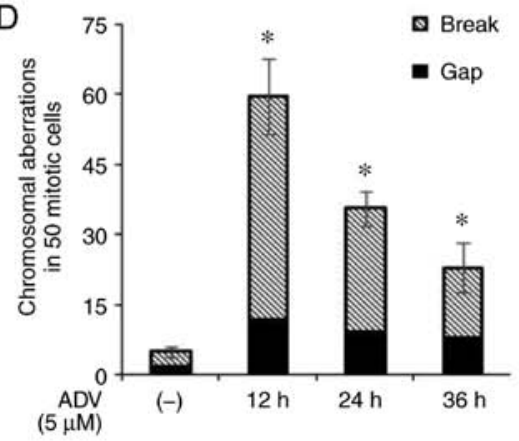

ADV $0.4 \mu \mathrm{M}$

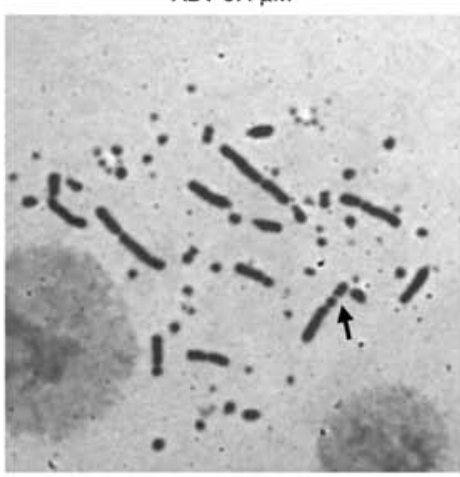

$\rightarrow$ Break

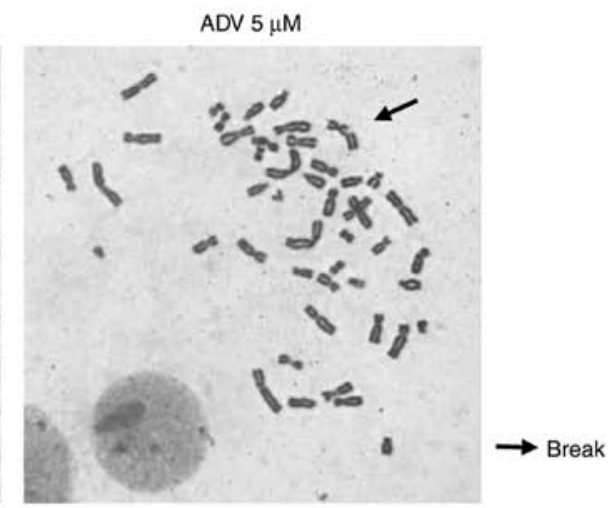

E

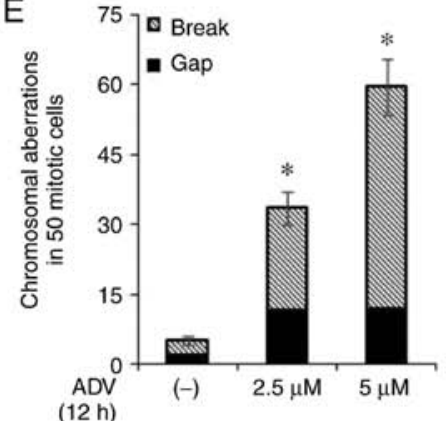

Figure 3. ADV induces DNA double-strand breaks in WT DT40 and TK6 cells. (A) Representative karyotype analysis of WT DT40 cells left untreated or exposed to $0.4 \mu \mathrm{M}$ ADV for $12 \mathrm{~h}$ (magnification, $\mathrm{x} 1,000$ ). (B) ADV induced CAs in WT DT40 cells depending on the concentration. Cells were exposed to 0.2 or $0.4 \mu \mathrm{M}$ ADV for 9-30 h. (C) Representative karyotype analysis of WT TK6 cells left untreated or exposed to $5 \mu \mathrm{M}$ ADV for $12 \mathrm{~h}$ (magnification, $\mathrm{x} 1,000$ ). (D) An increased frequency of CAs in WT TK6 cells was detected following treatment with $5 \mu \mathrm{M}$ ADV for 12-36 h. (E) Cells were exposed to 2.5 or $5 \mu \mathrm{M}$ ADV for $12 \mathrm{~h}$. ADV induced CAs in WT TK6 cells in a dose-dependent manner. Arrows indicate double-strand breaks. Values are expressed as the mean \pm standard deviation. ${ }^{*} \mathrm{P}<0.05$ vs. control. ADV, adefovir dipivoxil; $W T$, wild-type; CAs, chromosomal aberrations.

studies $(16,19)$. In the present study, the possible mechanisms underlying the genotoxic effects of ADV were assessed, and it was indicated that DSBs were generated following ADV treatment in WT DT40 and TK6 cells. Furthermore, the increase in $\gamma$-H2AX foci and CAs confirmed that DNA damage was induced by ADV. By determining the quantitative distribution of $\gamma$-H2AX foci in WT DT40 and TK6 cells, the DNA damage induced by ADV was described in detail. 
A

$\operatorname{ADV}(\mu \mathrm{M})$

$\begin{array}{llllll}0 & 0.06 & 0.12 & 0.18 & 0.24 & 0.3\end{array}$

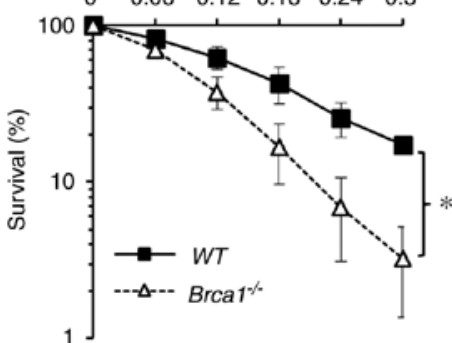

D

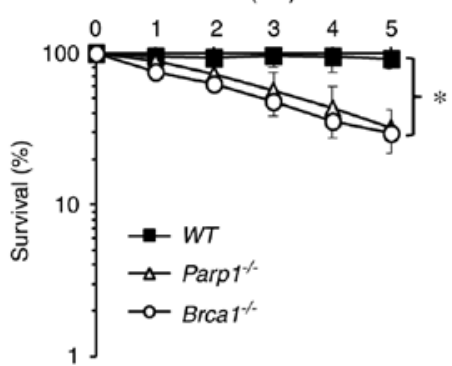

B

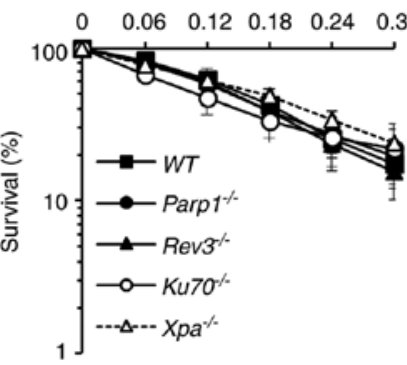

$\mathrm{E}$

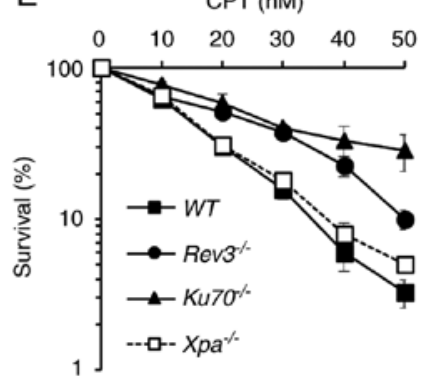

C

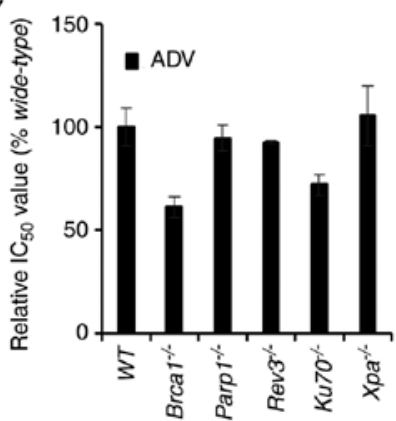

$\mathrm{F}$

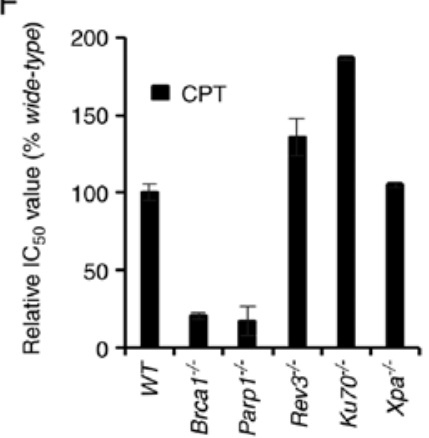

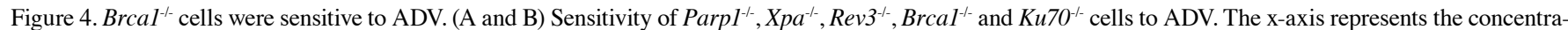
tion of ADV and the y-axis represents the relative percentage of surviving cells at $72 \mathrm{~h}$. (C) Relative IC ${ }_{50}$ values of ADV in DT40 cells. (D and E) Sensitivity of $\mathrm{Parpl}^{-/}, \mathrm{Xpa}^{-/}, \mathrm{Rev}^{-/}, \mathrm{Brcal}^{-/}$and $\mathrm{Ku} 7 \mathrm{O}^{-/}$cells to CPT. The X-axis represents the concentration of CPT and the y-axis represents the relative percentage of surviving cells at $72 \mathrm{~h}$. (F) Relative $\mathrm{IC}_{50}$ values of CPT in DT40 cells. Survival data were log-transformed to approximate normality. Two-way analysis of variance was used to test for differences in the linear dose-response curves between $W T$ cells and mutant cells. ${ }^{*} \mathrm{P}<0.05$, as indicated. ADV, adefovir dipivoxil; CPT, camptothecin; $W T$, wild-type; $\mathrm{IC}_{50}, 50 \%$ inhibitory concentration; Parpl $^{-/-}$, poly (adenosine diphosphate-ribose) polymerase deficient cells; Rev3 ${ }^{-/}$, REV3-like DNA directed polymerase $\zeta$ catalytic subunit deficient cells; $\mathrm{Ku} 7 \mathrm{O}^{-/-}$, Ku autoantigen $70 \mathrm{kDa}$ deficient cells; $\mathrm{Xpa}^{-/-}$, xeroderma pigmentosum group A-complementing protein deficient cells.

A

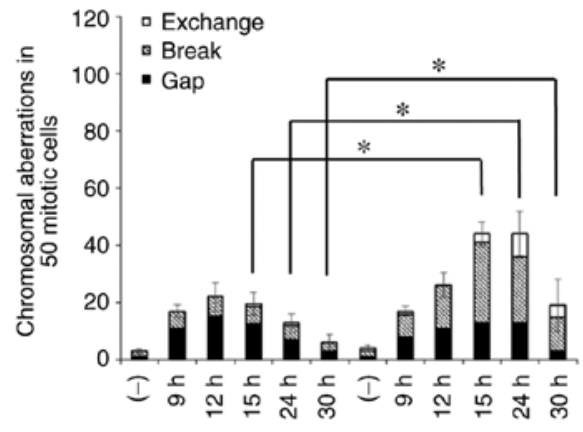

DT40

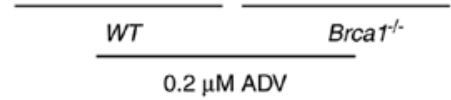

C

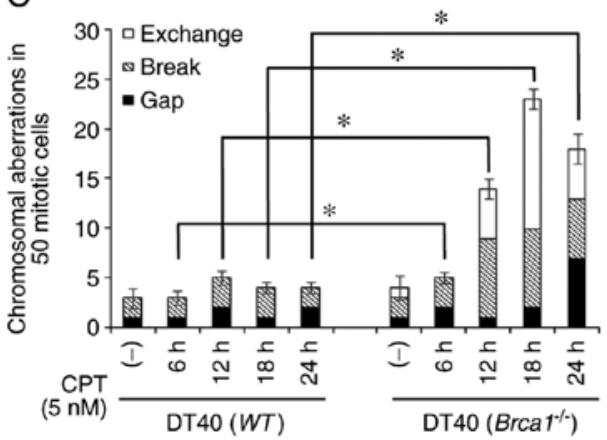

B

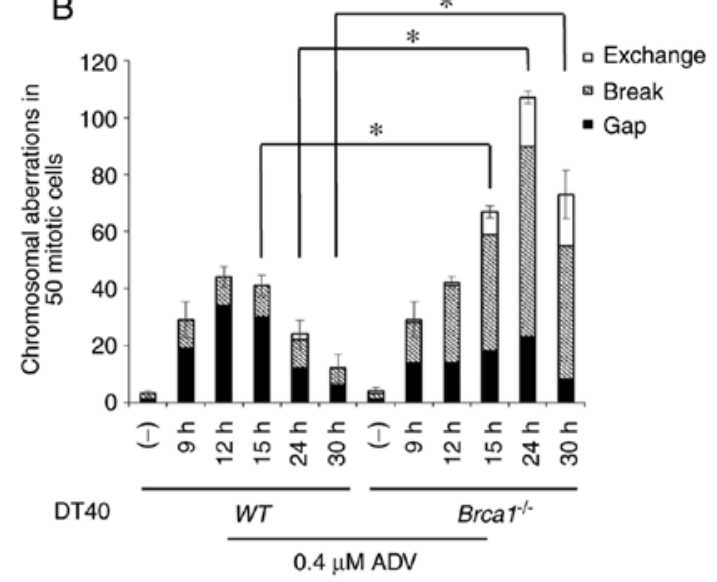

$\mathrm{D}$

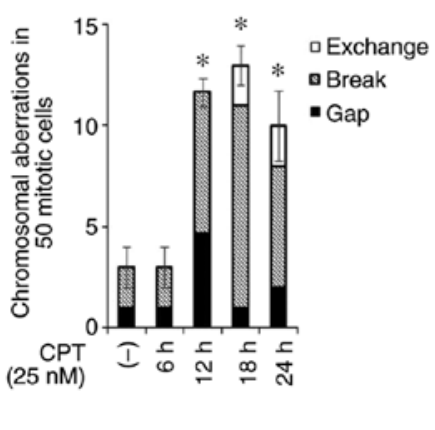

Figure 5. $\mathrm{Brcal}^{-/-}$cells exhibit increased DNA double-strand breaks in response to ADV and CPT. (A and B) CAs in Brca $1^{-/-}$and $\mathrm{WT}$ cells following treatment with ADV $(0.2$ or $0.4 \mu \mathrm{M})$ for 9-30 h. (C) CAs in Brcal ${ }^{-/-}$and WT cells following treatment with CPT (5 nM) for 6-24 h. *P<0.05, as indicated. (D) WT DT40 cells were exposed to $25 \mathrm{nM}$ CPT for 6-24 h. "P<0.05 vs. control (-). ADV, adefovir dipivoxil; CPT, camptothecin; CAs, chromosomal aberrations; WT, wild-type. 
To the best of our knowledge, the present study was the first to screen the sensitivity of a series of isogenic DNA repair-deficient cell lines to ADV in a quantitative manner. These cell lines include a base excision repair-mutant $\left(\right.$ Parpl $\left.^{-/-}\right)$, a homologous recombination (HR) repair mutant $\left(\mathrm{BrCal}^{-/}\right)$, a non-homologous end-joining (NHEJ) repair mutant $\left(K u 70^{-/-}\right)$, a translesion DNA synthesis repair-mutant $\left(\operatorname{Rev}^{-/}\right)$and a nucleotide excision repair-mutant $\left(\mathrm{Xpa}^{-/}\right)$. Notably, the sensitivity profile $\left(\mathrm{IC}_{50}\right)$ evaluation indicated that only $\mathrm{Brcal}^{-/-}$cells displayed a higher sensitivity to ADV compared with any other DNA repair-deficient cell lines. The increased CAs in Brcal $^{-/}$cells compared with the WT cell line reflected that Brcal may have a critical role in preventing ADV-induced CAs. These results suggested that ADV may be genotoxic with Brcal dependence. The results of the clonogenic assays also confirmed that $\mathrm{BrCal}^{-/-}$cells were significantly more sensitive to ADV when compared with WT DT40 cells.

Brcal protein is generally considered as not only a tumor suppressor but a DNA repair factor involved in multiple DNA repair and genome stability processes (42-44). Much of the research on DNA repair associated with Brcal has focused on HR repair as well as NHEJ $(30,45,46)$. Firstly, Brca1 has an important role in the HR of DSBs, which is comprised of the dynamic removal of NHEJ proteins from DSBs to prevent inappropriate end-ligation and promote reliable sister chromatid repair (47-50). Secondly, Brca1 is also associated with NHEJ (51). DNA breaks in $\mathrm{Brcal}^{-/-}$cells are abnormally connected to complex chromosome rearrangements via NHEJ factor tumor protein p53 binding protein 1 (53BP1). 53BP1 is able to block the resection of DNA breaks and inhibit HR in $\mathrm{BrCal}^{-/-}$cells. The capacity of $\mathrm{BrCal}^{-/-}$cells to accurately repair DSBs is limited by the presence of 53BP1. HR and NHEJ compete to deal with DNA breaks (51). Brca1 and 53BP1 adjust the balance between HR and NHEJ, which may be used to selectively protect or kill $\mathrm{Brcal}^{-/-}$cells (51).

The present results illustrated that $K u 70^{-/-}$cells did not have an increased sensitivity to ADV compared with $W T$ DT40 cells. Furthermore, the results also demonstrated that 53BP1-deficient cells had a similar viability following treatment with ADV compared with WT TK6 cells (data not shown). Based on all of these results, it was concluded that Brcal took part in the repair of ADV-induced DNA damage, and the molecular mechanisms may mainly be associated with HR.

In conclusion, ADV-induced cellular genotoxicity in DT40 and TK6 cells, and Brcal are involved in tolerance to DNA damage induced by ADV. The present results suggest that it is necessary to monitor the genotoxicity of ADV and to restrict the usage or limit the treatment period. A better understanding of the mechanisms underlying ADV-induced genotoxicity may contribute to the development of novel drugs against $\mathrm{CHB}$ with higher therapeutic efficacy and less genotoxicity. To date, at least 6 NAs have been approved for HBV treatment, including telbivudine, lamivudine, ETV, ADV, tenofovir alafenamide and tenofovir disoproxil fumarate (6-8). However, further research on their molecular mechanisms is worthwhile.

\section{Acknowledgements}

Not applicable.

\section{Funding}

The present study was supported by the National Natural Science Foundation of China (grant no. 81373431) and the Science and Technology Support Program of Sichuan Province, China (grant no. 2012SZ0147).

\section{Availability of data and materials}

All data generated or analyzed during this study are included in this article and in the supplementary materials.

\section{Authors' contributions}

YQ, XW and HL conceived and designed the experiments. HL and ZC performed the experiments. HL, YQ, XW, YW and $\mathrm{FH}$ analyzed the data. ZZ, CX, XF and XB performed part of chromosome aberration analysis work for TK6 cells and analyzed the data. HL, XW, YQ, YW and FH wrote the paper. ST generated the gene knockout cells. All authors have read and approved the final manuscript.

\section{Ethics approval and consent to participate}

Not applicable.

\section{Patient consent for publication}

Not applicable.

\section{Competing interests}

The authors declare that they have no competing interests.

\section{References}

1. Zhou TC, Li X, Chen LJ, Fan JH, Lai X, Tang Y, Zhang L and Wei J: Differential expression profile of hepatic circular RNAs in chronic hepatitis B. J Viral Hepat 25: 1341-1351, 2018.

2. Sarin SK, Kumar M, Lau GK, Abbas Z, Chan HL, Chen CJ, Chen DS, Chen HL, Chen PJ, Chien RN, et al: Asian-Pacific clinical practice guidelines on the management of hepatitis B: A 2015 update. Hepatol Int 10: 1-98, 2016

3. Hu J, Cheng J, Tang L, Hu Z, Luo Y, Li Y, Zhou T, Chang J and Guo JT: Virological basis for the cure of chronic hepatitis B. ACS Infect Dis, 2018.

4. Yang HC and Kao JH: Persistence of hepatitis B virus covalently closed circular DNA in hepatocytes: Molecular mechanisms and clinical significance. Emerg Microbes Infect 3: e64, 2014.

5. Zoulim F: New insight on hepatitis B virus persistence from the study of intrahepatic viral cccDNA. J Hepatol 42: 302-308, 2005.

6. European Association for the Study of the Liver: EASL clinical practice guidelines: Management of chronic hepatitis B virus infection. J Hepatol 57: 167-185, 2012.

7. Terrault NA, Bzowej NH, Chang KM, Hwang JP, Jonas MM and Murad MH; American Association for the Study of Liver Diseases: AASLD guidelines for treatment of chronic hepatitis B. Hepatology 63: 261-283, 2016.

8. Lok AS, McMahon BJ, Brown RS Jr, Wong JB, Ahmed AT, Farah W, Almasri J, Alahdab F, Benkhadra K, Mouchli MA, et al: Antiviral therapy for chronic hepatitis B viral infection in adults: A systematic review and meta-analysis. Hepatology 63: 284-306, 2016.

9. European Association for the Study of the Liver. Electronic address easloffice@easloffice.eu; European Association for the Study of the Liver: EASL 2017 clinical practice guidelines on the management of hepatitis B virus infection. J Hepatol 67: 370-398, 2017. 
10. Terrault NA, Lok ASF, McMahon BJ, Chang KM, Hwang JP Jonas MM, Brown RS Jr, Bzowej NH and Wong JB: Update on prevention, diagnosis, and treatment of chronic hepatitis B: AASLD 2018 hepatitis B guidance. Hepatology 67: 1560-1599, 2018.

11. Tong S and Revill P: Overview of hepatitis B viral replication and genetic variability. J Hepatol 64 (Suppl 1): S4-S16, 2016.

12. Ghany MG: Current treatment guidelines of chronic hepatitis B: The role of nucleos $(\mathrm{t})$ ide analogues and peginterferon. Best Pract Res Clin Gastroenterol 31: 299-309, 2017.

13. Lai CL, Wong D, Ip P, Kopaniszen M, Seto WK, Fung J, Huang FY, Lee B, Cullaro G, Chong CK, et al: Reduction of covalently closed circular DNA with long-term nucleos(t)ide analogue treatment in chronic hepatitis B. J Hepatol 66: 275-281, 2017.

14. Nassal M: HBV cccDNA: Viral persistence reservoir and key obstacle for a cure of chronic hepatitis B. Gut 64: 1972-1984, 2015.

15. Tacke F and Kroy DC: Treatment for hepatitis B in patients with drug resistance. Ann Transl Med 4: 334, 2016.

16. Jiang L, Wu X, He F, Liu Y, Hu X, Takeda S and Qing Y: Genetic evidence for genotoxic effect of entecavir, an anti-Hepatitis B virus nucleotide analog. PLoS One 11: e0147440, 2016.

17. Choi J, Kim HJ, Lee J, Cho S, Ko MJ and Lim YS: Risk of hepatocellular carcinoma in patients treated with entecavir vs tenofovir for chronic hepatitis B: A Korean nationwide cohort study. JAMA Oncol 5: 30-36, 2018.

18. Cartus A and Schrenk D: Current methods in risk assessment of genotoxic chemicals. Food Chem Toxicol 106: 574-582, 2017.

19. US Food and Drug Administration: Draft guidance on Adefovir Dipivoxil. https://www.fda.gov/downloads/Drugs/Guidance ComplianceRegulatoryInformation/Guidances/UCM136541.pdf

20. Baba TW, Giroir BP and Humphries EH: Cell lines derived from avian lymphomas exhibit two distinct phenotypes. Virology 144 139-151, 1985.

21. Bryce SM, Bemis JC, Avlasevich SL and Dertinger SD: In vitro micronucleus assay scored by flow cytometry provides a comprehensive evaluation of cytogenetic damage and cytotoxicity. Mutat Res 630: 78-91, 2007.

22. Ellinger-Ziegelbauer H, Fostel JM, Aruga C, Bauer D, Boitier E, Deng S, Dickinson D, Le Fevre AC, Fornace AJ Jr, Grenet O, et al: Characterization and interlaboratory comparison of a gene expression signature for differentiating genotoxic mechanisms. Toxicol Sci 110: 341-352, 2009

23. Fellows MD and O'Donovan MR: Etoposide, cadmium chloride, benzo[a]pyrene, cyclophosphamide and colchicine tested in the in vitro mammalian cell micronucleus test (MNvit) in the presence and absence of cytokinesis block using L5178Y mouse lymphoma cells and 2-aminoanthracene tested in MNvit in the absence of cytokinesis block using TK6 cells at AstraZeneca UK, in support of OECD draft Test Guideline 487. Mutat Res 702: 163-170, 2010.

24. Platel A, Nesslany F, Gervais V and Marzin D: Study of oxidative DNA damage in TK6 human lymphoblastoid cells by use of the in vitro micronucleus test: Determination of no-observed-effect levels. Mutat Res 678: 30-37, 2009.

25. Sonoda E, Okada T, Zhao GY, Tateishi S, Araki K, Yamaizumi M, Yagi T, Verkaik NS, van Gent DC, Takata M and Takeda S: Multiple roles of Rev3, the catalytic subunit of polzeta in maintaining genome stability in vertebrates. EMBO J 22: 3188-3197, 2003.

26. Okada T, Sonoda E, Yamashita YM, Koyoshi S, Tateishi S, Yamaizumi M, Takata M, Ogawa O and Takeda S: Involvement of vertebrate polkappa in Rad18-independent postreplication repair of UV damage. J Biol Chem 277: 48690-48695, 2002

27. Masson M, Niedergang C, Schreiber V, Muller S, Menissierde Murcia J and de Murcia G: XRCC1 is specifically associated with poly(ADP-ribose) polymerase and negatively regulates its activity following DNA damage. Mol Cell Biol 18: 3563-3571, 1998.

28. Qing Y, Yamazoe M, Hirota K, Dejsuphong D, Sakai W, Yamamoto KN, Bishop DK, Wu X and Takeda S: The epistatic relationship between BRCA2 and the other RAD51 mediators in homologous recombination. PLoS Genet 7: e1002148, 2011.

29. Takata M, Sasaki MS, Sonoda E, Morrison C, Hashimoto M, Utsumi H, Yamaguchi-Iwai Y, Shinohara A and Takeda S: Homologous recombination and non-homologous end-joining pathways of DNA double-strand break repair have overlapping roles in the maintenance of chromosomal integrity in vertebrate cells. EMBO J 17: 5497-5508, 1998.
30. Rosen EM: BRCA1 in the DNA damage response and at telomeres. Front Genet 4: 85, 2013.

31. Carmichael J, DeGraff WG, Gazdar AF, Minna JD and Mitchell JB: Evaluation of a tetrazolium-based semiautomated colorimetric assay: Assessment of chemosensitivity testing. Cancer Res 47: 936-942, 1987.

32. Hu X, Wu X, Liu H, Cheng Z, Zhao Z, Xiang C, Feng X, Takeda S and Qing Y: Genistein-induced DNA damage is repaired by nonhomologous end joining and homologous recombination in TK6 cells. J Cell Physiol 234: 2683-2692, 2019.

33. Mosmann T: Rapid colorimetric assay for cellular growth and survival: Application to proliferation and cytotoxicity assays. J Immunol Methods 65: 55-63, 1983.

34. Sonoda E, Sasaki MS, Buerstedde JM, Bezzubova O, Shinohara A, Ogawa H, Takata M, Yamaguchi-Iwai Y and Takeda S: Rad51-deficient vertebrate cells accumulate chromosomal breaks prior to cell death. EMBO J 17: 598-608, 1998.

35. An international system for human cytogenetic nomenclature (1978) ISCN (1978). Report of the standing commitee on human cytogenetic nomenclature. Cytogenet Cell Genet 21: 309-409, 1978.

36. Yamamoto KN, Hirota K, Kono K, Takeda S, Sakamuru S, Xia M, Huang R, Austin CP, Witt KL and Tice RR: Characterization of environmental chemicals with potential for DNA damage using isogenic DNA repair-deficient chicken DT40 cell lines. Environ Mol Mutagen 52: 547-561, 2011.

37. Ji K, Kogame T, Choi K, Wang X, Lee J, Taniguchi Y and Takeda S: A novel approach using DNA-repair-deficient chicken DT40 cell lines for screening and characterizing the genotoxicity of environmental contaminants. Environ Health Perspect 117: 1737-1744, 2009.

38. Dickey JS, Redon CE, Nakamura AJ, Baird BJ, Sedelnikova OA and Bonner WM: H2AX: Functional roles and potential applications. Chromosoma 118: 683-692, 2009.

39. Liu Y, Wu X, Hu X, Chen Z, Liu H, Takeda S and Qing Y: Multiple repair pathways mediate cellular tolerance to resveratrol-induced DNA damage. Toxicol In Vitro 42: 130-138, 2017.

40. Ibuki Y and Toyooka T: Evaluation of chemical phototoxicity, focusing on phosphorylated histone H2AX. J Radiat Res 56: 220-228, 2015.

41. Solovjeva L, Firsanov D, Pleskach N and Svetlova $\mathrm{M}$ Immunofluorescence analysis of gamma-H2AX Foci in mammalian fibroblasts at different phases of the cell cycle. Methods Mol Biol 1644: 187-194, 2017.

42. Scully R and Livingston DM: In search of the tumour-suppressor functions of BRCA1 and BRCA2. Nature 408: 429-432, 2000.

43. Tarapore P, Hanashiro K and Fukasawa K: Analysis of centrosome localization of BRCA1 and its activity in suppressing centrosomal aster formation. Cell Cycle 11: 2931-2946, 2012.

44. Pathania S, Bade S, Le Guillou M, Burke K, Reed R, Bowman-Colin C, Su Y, Ting DT, Polyak K, Richardson AL, et al: BRCA1 haploinsufficiency for replication stress suppression in primary cells. Nat Commun 5: 5496, 2014.

45. Moynahan ME, Chiu JW, Koller BH and Jasin M: Brcal controls homology-directed DNA repair. Mol Cell 4: 511-518, 1999.

46. Turner N, Tutt A and Ashworth A: Hallmarks of 'BRCAness' in sporadic cancers. Nat Rev Cancer 4: 814-819, 2004.

47. Prakash R, Zhang Y, Feng W and Jasin M: Homologous recombination and human health: The roles of BRCA1, BRCA2, and associated proteins. Cold Spring Harb Perspect Biol 7: a016600, 2015.

48. Chen L, Nievera CJ, Lee AY and Wu X: Cell cycle-dependent complex formation of BRCA1.CtIP.MRN is important for DNA double-strand break repair. J Biol Chem 283: 7713-7720, 2008.

49. Sartori AA, Lukas C, Coates J, Mistrik M, Fu S, Bartek J, Baer R, Lukas J and Jackson SP: Human CtIP promotes DNA end resection. Nature 450: 509-514, 2007.

50. Yu X, Wu LC, Bowcock AM, Aronheim A and Baer R: The C-terminal (BRCT) domains of BRCA1 interact in vivo with CtIP, a protein implicated in the CtBP pathway of transcriptional repression. J Biol Chem 273: 25388-25392, 1998.

51. Bunting SF, Callén E, Wong N, Chen HT, Polato F, Gunn A, Bothmer A, Feldhahn N, Fernandez-Capetillo O, Cao L, et al: 53BP1 inhibits homologous recombination in Brca1-deficient cells by blocking resection of DNA breaks. Cell 141: 243-254, 2010. 